\title{
Die Proponentsondertekeningsformule van die Nederduitsch Hervormde Kerk van
}

\author{
Afrika
}

\author{
S J Botha \\ Departement Kerkgeskiedenis \\ Universiteit van Pretoria
}

\begin{abstract}
The formula which must be signed by candidate ministers of the Nederduitsch Hervormde Kerk van Afrika

This article presents research on the way the tradition of the Reformed Churches according to which candidate ministers have to sign a formula, found its way into the Nederduitsch Hervormde Church, and on the degree to which this tradition was upheld in the Church. Although the Church recently accepted a totally rewritten Church Order, the existing formula was maintained with only minor and non-essential changes.
\end{abstract}

\section{INLEIDING}

In Junie 1997 het die Nederduitsch Hervormde Kerk 'n nuwe kerkorde aanvaar. In Ordereël 1 word daar gestel dat die belydenis van die Kerk verwoord is in die drie ekumeniese belydenisse, asook in die drie Reformatoriese belydenisskrifte. In Ordinansie 1.1.1 word bepaal dat die binding aan die belydenis, soos vervat in die belydenisse en belydenisskrifte, vir alle lidmate geld. In lyn met die tradisie in die reformatoriese kerke, is ook in die Kerkorde van die Nederduitsch Hervormde Kerk 'n formule opgeneem wat kandidate vir die amp van dienaar van die Woord verplig is om te onderteken (Kerkorde 1998: Ordinansie 1.1.2). Word die formule vergelyk met die formule wat vanaf 1866 tot 1997 in die kerkwet van die Nederduitsch Hervormde Kerk van krag was, 
is dit duidelik dat, ten spyte van veranderings wat wel aangebring is, daar nie wesenlike verskil bestaan nie. In die debat wat die aanvaarding van die Kerkorde voorafgegaan het, was daar nooit enige voorstelle dat die formule afgeskaf moes word nie. Dit is dus 'n tradisie wat vir almal binne die Kerk ook aanvaarbaar is.

\section{DIE ONDERTEKENINGSFORMULE IN DIE KERK AAN DIE KAAP}

Die gemeentes aan die Kaap was tot by die finale oorname van die Kaap deur Engeland in 1806, deel van die Nederlandse Hervormde Kerk. Die gemeentes is selfs nie eers toegelaat om as afsonderlike klassis te konstitueer nie, maar het onder die klassis Amsterdam ressorteer. Ook die predikante het of uit Nederland gekom of is daar opgelei. Daarom was daar geen nodigheid vir die kerk aan die Kaap om 'n ondertekeningsformule te hê nie. Selfs nie eers by die opstel van 'n eie kerkorde in 1824 is daar 'n eie ondertekeningsformule vir predikante opgestel nie. 'n Belangrike rede hiervoor was natuurlik die feit dat daar geen eie predikanteopleiding aan die Kaap was nie en dat daar ook geen sprake van 'n moontlikheid in die verband was nie. Predikante uit Nederland het immers aanvanklik die formule van die klassis Amsterdam, wat waarskynlik wel die Dordtse formule was, onderteken. $\mathrm{Na} 1816$ is die nuwe formule deur hulle onderteken. Ook die Skotse predikante wat sedert die twintigerjare na die Kaap gekom het, het vermoedelik dieselfde formule onderteken. Tot 1837 was daar geen kwessies rondom die ondertekeningsformule nie.

Dit is van belang om terloops daarop te wys dat die kerkorde van 1824 , bekend as die Algemeen Reglement voor het bestuur der Nederduitsch Hervormde Kerk, in ZuidAfrika, die Algemeen Reglement van 1816 van die Nederlandse Hervormde Kerk as voorbeeld en die 1804-ordonnansie van De Mist as basis gehad het. Met die gevolg dat die eerste eie kerkorde op Suid-Afrikaanse bodem 'n duidelike sekulêre strukturering van die kerk vertoon het, in lyn met die verenigingsregdenke wat uit die Aufklärung afkomstig was. 
Hoewel geen ondertekeningsformule in die Algemeen Reglement opgeneem is nie, is merkwaardig genoeg in artikel 35 ten opsigte van die godsdiensonderwysers bepaal:

Niemand zal, zelfs na afgelegd voldoend Examen, dat werk mogen uitoefenen, dan na goedgekeurd zynde, de volgende verklaring te hebben onderteekend:

Wy ondergetekenden, by het Kerkbestuur van ... geexamineerd en toegelaten tot het geven van Godsdienstig Onderwys, verklaren in goede gemoede, de Leer welke overeenkomstig Gods Heilig Woord vervat is, in de formulieren van eenigheid der Nederlandsche Hervormde Kerk, hartelyk te omhelzen, belovende, dezelve by ons onderwys getrouwelyk te zullen leeren, en ons overeenkomstig het Reglement op het Godsdienstig Onderwys in alles stiptelyk te zullen gedragen; ons onderwerpen aan den oordeel van den Kerkenraad, indien daartegen door ons mogt gehandel worden

(Pont 1991:222)

Voor die sinode van 1837 het daar twee beskrywingspunte rakende die saak gedien, een van dr W Robertson en die ander van die kerkraad van Somerset. Die kerkraad van Somerset het gevra "Dat een Formulier van Geloofsbelijdenis of Verklaring en Belofte door de Synode vervaardigd worde, welke de voor deze Kolonie uitkomende Predikanten zullen moeten onderteeken, wanneer zij zich bij den Actuarius Synodi legitimeren"(in Kleynhans 1973:158). Dr Robertson het weer betoog dat “ ... de thans bestaande Acte van ondertekening van Predikanten den weg openlaat tot zekere reserve ..." en daarom wou hy die formule gewysig hê (Kleynhans 1973:159). Die twee beskrywingspunte was egter nie die eerste aanduidings dat daar 'n debat in die kerk aan die gang was rondom die saak van 'n ondertekeningsformule nie. Reeds in 1836 het die ring van Graaff-Reinet besluit om by die aktuarius van die sinode te vra of van die Kaapse predikante by toelating “ ... vereischt wordt de Geloofs artikelen van onze Kerk zonder eenige reservatie te onderteekenen, en zoo niet op welke wijze het legitimeer en geschiedt" (in Kleynhans 1973:157). Sowel die vraag as die twee beskrywingspunte se oorsprong kan teruggevoer word na onrus oor gebeure op kerklike werf in Nederland 
rondom die ondertekeningsformule wat sedert 1816 daar van krag geword het. Dit het egter ook twee verdere sake aan die lig gebring. Eerstens dat in die Kaapse kerk self onsekerheid omtrent die ondertekeningsformule bestaan het. Tweedens dat in die Kaapse kerk self ook reeds skerp verdeeldheid oor die bewoording van so ' $n$ formule bestaan het. Die gevolg was dat selfs die kompromieverklaring van die sinode "... dat de ondertekenaar van de Acte by de Legitimatie door zijne onderteekening verklaart en te kennen geeft, dat hij de leer, die in de Formulieren van Eenigheid vervat is, gelooft overeenkomstig Gods Heilig Woord te zijn "met 'n meerderheid van slegs 21 stemme teenoor 19 aanvaar is" (Kleynhans 1973:159).

By die sinode van 1842 is 'n nuwe kerkwet vir die Kaapse kerk aanvaar en dit het as Ordonnansie 7 van 1843 van owerheidsweë regskrag gekry. Ook in hierdie kerkwet is ruimskoots bepalings oorgeneem uit die Algemeen Reglement van die Nederlandse Hervormde Kerk, hoewel die formulering van die ondertekeningsformule geneig het in die rigting dat die formuliere onderteken word omdat hulle met die Woord van God ooreenkom (Pont 1991:266). Die ter sake gedeelte in die amptelike Engelse teks van Ordonnansie 7 het gelui: “... that I faithfully embrace and heartily believe as agreeable to God's holy word the doctrine contained in the adopted formulas of uniformity of the reformed church ..." (Pont 1991:266). Tog kom die vraag na vore wat die presiese betekenis van die woord agreeable sou wees. In Nederlands het die betrokke gedeelte van artikel 62 gelees: “. .. dat ik de leer, in de aangenomen formulieren van Eenigheid der Gereformeerde Kerk vervat ter goeder trouw aanneem en hartelyk geloof als overeenkomstig Gods Heilig Woord; ..." (in Kleynhans 1973:160). Kleynhans wys dan daarop dat in artikel 63 ook nog bepaal is “... dat 'n leraar, met sy ondertekenig van die akte van toelating by die legitimasie, te kenne gee dat hy die leer "welke in het formulier van Eenigheid der Gereformeerde Kerk vervat is, beschouwd overeenkomstig Gods Heilig Woord te zijn." Tereg wys Pont daarop dat hier die vraag gestel kan word wat die presiese betekenis van die woord beschouwd sou wees (Pont 1991: 270).

Behalwe die vrae oor die presiese betekenis van sekere woorde, is daar ook nog die vraag watter formuliere onder "adopted formulas" of "aangenomen formulieren" ingesluit is. 
In 1873 het die ondertekeningsformule in die Kaapse Nederduitse Gereformeerde Kerk ' $n$ verdere wysiging ondergaan, en is van die kandidaat verwag "dat hy by sy toelating plegtig sal verklaar, en met sy handtekening sal bevestig, dat hy van harte glo "dat al de Artikelen en Stukken der Leer, in de Nederlandsche Geloofsbelijdenis, den Heidelbergschen Catechismus en de Dordtse Leerregels, zijnde Formulieren van Eenigheid der Gereformeerde Kerken van Nederland, begrepen, met Gods Woord overeenkomen" (Kleynhans 1973:165). Van kandidate wat aan 'n ander erkende universiteit of seminarium opgelei is maar in die Kerk vir diens aanmeld, is verwag om hulle aan 'n Colloquium doctum te onderwerp. Behalwe as toetssteen van wetenskplike en godgeleerde bekwaamheid, was die Colloquium veral ook 'n ondersoek “ ... naar de gevoelen

omtrent de wedergeboorte door den Heiligen Geest, ... de persoonlijke ondervinding van Gods genade, alsmede omtrent de gehegtheid aan de leer onzer kerk, welke de Synode verstaan wil hebben als onmisbare vereischten te zijn voor allen die zich als leeraars aanbieden" (Kleynhans 1973:165).

\section{EIE ONDERTEKENINGSFORMULE VIR DIE NEDER- DUITSCH HERVORMDE KERK}

Aanvanklik het die gemeentes van die Voortrekkerkerk die Algemeen Reglement van 1824, met die nodige aanpassings vir hulle besondere omstandighede, gebruik. Selfs nadat die Transvaalse gemeentes in 1853 hulle lankbestaande selfstandigheid en onafhanklikheid bevestig het deur hulle as Nederduitsch Hervormde Kerk te organiseer, het die gebruik nog vir 'n tyd lank voortgesit. Hoewel reeds sedert 1857 'n nie-amptelike eie kerkwet in gebruik was, het die eerste amptelike kerkwet, deur die owerheid goedgekeur en deur wetgewing bekragtig, eers in 1863 begin funksioneer (Pont 1963:36ev; Botha 1963:25ev). Nêrens is daar egter 'n ondertekeningsformule ingesluit nie, ook omdat die predikante almal van buite afkomstig was en dit vir die Kerk aanvaarbaar was dat die inkomende predikante in die Kaapse Kerk gelegitimeer is. Toe die Kaapse Kerk in 1863 besluit het om die legitimasie van di Van der Hoff, Begemann en Smits in te trek, selfs sonder om hulle daarvan kennis te gee, het die Nederduitsch Hervormde Kerk besluit om voortaan ook hierdie funksie self te hanteer (Engelbrecht 1953:171). Aan di Dirk van der Hoff en A J Begemann is opdrag gegee om 'n konsepformule op te stel wat op 26 Februarie 1866 deur die Algemene Kerkvergadering aanvaar en bekragtig is: 
Wij, ondergeteekenden, Predikanten van de Nederduitsche Hervormde Kerk, verklaren in goeden gemoede de leer welke overeenkomstig Gods Heilig Woord vervat is in de formulieren van eenigheid der Nederduitsche Hervormde Kerk, $\mathrm{nl}$ de Nederlandsche Geloofsbelijdenis, de Heidelbersche Catechismus en de Dordtse leerregelen, hartelijk te zullen omhelzen en getrouw te zullen leeren, belovende ons in alles overeenkomstig onze kerkelijke Reglementen stiptelijk te zullen gedragen, ons onderwerpende aan het ordeel der bevoegde kerkelijke besturen alhier, indien daartegen door ons mocht worden gehandeld. De ondertekenaar van deze formule verklaart door zijne handteekening, dat hij de leer, die in bovengenoemde formulieren is vervat, gelooft overeenkomstig Gods Woord te zijn.

(Aangehaal in Engelbrecht 1953:214)

Hierdie formule is presies so in Nederlandse vorm behou totdat dit eers in 1964, lank nadat die Kerkwet reeds in Afrikaans in gebruik gekom het, soos volg deur die Algemene Kerkvergadering in Afrikaans bekragtig is:

Ons die ondergetekendes, predikante van die Nederduitsch Hervormde Kerk in die Republiek van Suid-Afrika, verklaar hiermee plegtig dat ons die leer wat ooreenkomstig die heilige Woord van God vervat is in die Formuliere van Enigheid van die Nederduitsch Hervormde Kerk, naamlik die Nederlandse Geloofsbelydenis, die Heidelbergse Kategismus en die Dordtse Leerreëls, van harte onderskryf en getrou sal leer. Verder beloof ons om ons in alles stip volgens die Kerkwet en Bepalings te gedra; en indien ons daarteen mag handel, beloof ons om ons aan die oordeel van bevoegde kerklike vergaderinge alhier te onderwerp.

Die ondertekenaar van hierdie formule verklaar deur sy handtekening dat hy glo dat die leer in die genoemde formuliere in ooreenstemming is met die Woord van God.

(NHKA 1964:67)

Inhoudelik was daar egter geen verskil tussen die oorspronklike Nederlands en die Afrikaanse weergawe nie. Hierdie Afrikaanse vertaling is in 1979 saam met die Kerkwet 
en Bepalings taalkundig versorg en toe het daar wel 'n uitbreiding en verandering na vore gekom waarop later teruggekom word. Deur die handhawing van hierdie ondertekeningsformule kon die Nederduitsch Hervormde Kerk die leer van die kerk, soos uitgedruk in die belydenisskrifte van die Kerk, ongeskonde bewaar.

\section{7. 'N VOORSTEL OM DIE ONDERTEKENINGSFORMULE TE VERANDER}

In die meer as 'n eeu tussen 1866 en 1979 is daar slegs by een geleentheid veranderinge aan die ondertekeningsformule voorgestel en dit was by die Algemene Kerkvergadering van 1888, wat die eerste Algemene Kerkvergadering na die mislukte kerkvereniging van 1885 was. Nadat ds M J Goddefroy, wat in Nederland die noodroep van die gedisorganiseerde Nederduitsch Hervormde Kerk gehoor het en bereid was om 'n beroep na die kombinasie Pretoria-Middelburg-Standerton (Trichardtsfontein) te aanvaar en sodoende die enigste predikant in die hele Kerk te wees (Botha 1981:533ev), die voorlopige reorganisasiewerk op plaaslike vlak afgehandel het, is die volgende stap in sy reorganisasieplan naamlik die byeenroep van die Algemene Kerkvergadering, geïmplementeer. Een van die sake wat tydens die Vergadering ter hand geneem is, was die hersiening van die Kerkwet van 1869. Voor die Vergadering het 'n "concept-acte van wijzigingen", opgestel deur 'n kommissie onder leiding van Goddefroy, gedien. Onder die wysigings wat voorgestel is, was daar ook ' $n$ voorstel tot wysiging van die ondertekeningsformule. Die wesenlik verskil tussen die bestaande formule en die nuwe voorstel was daarin geleë dat voortaan nie van die kandidaat verwag sou word om 'n formule te onderteken waarin " ... hij belooft getrouw en oprecht de leer van die Ned Herv Kerk te prediken...", maar wel dat hy 'n formule moes onderteken waarin he verklaar dat hy " ... oprechtelijk het Evangelie der Genade overeenkomstig Gods Woord en in overeenstemming met de formulieren der Ned Herv Kerk, zooals die zijn vastgesteld door de Nationale Sijnode van Dordrecht in 1619 en 1619 te zullen prediken en leeren" (NHKA 1888:22). Goddefroy het die voorstel onder andere soos volg toegelig: 
... dat het onmogelijk is om volgens de oude formule te belooven de leer ener Kerk te verkondigen. De predikanten hebben een hoogere roeping dan het verkondiging eener Kerkleer, namelijk het prediken van het Evangelie der behoudenis overeenkomstig Gods Woord aan Zondaren. En deze zullen eerder tot Christus gebracht worden door het prediken zijner leer inliefde en waarheid, dan door het verkondigen eener kerkleer.

(NHKA 1888:23)

Goddefroy het sy standpunt gegrond op die Skrif en die bevestigingsformulier vir dienaars van die Woord (Botha 1981:68). Die grondsaak waaroor dit vir hom gegaan het, was egter dat hy bekommerd was dat Gods Woord en mensewoord (= kerkleer) nie op dieslfde vlak gestel moes word nie. Daarom was die predikant nie geroep om 'n kerleer te verkondig nie maar die evangelie van genade, hy is immers dienaar van die Woord en nie dienaar van die kerkleer nie. Dit het egter hoegenaamd nie vir hom ingehou dat die kerkleer daarmee op enige wyse verwerp of selfs geringgeskat sou word of dat leer vryheid ingevoer moes word nie. Ongekwalifiseerd het hy die standpunt van Dordt onderskryf en verklaar dat die dienaar van die Woord verplig was om hom in sy verkondiging aan die leer van die Kerk te hou. Hoewel die predikant slegs die evangelie moes verkondig, moes die verkondiging geskied in ooreenstemming met die belydenis (= leer) van die Kerk (Botha 1981:69).

Hoewel die Algemene Kerkvergadering hierdie gewysigde ondertekeningsformule eenparig aanvaar het, het dit nooit van krag geword nie, omdat die Kerkwet van 1869 onveranderd behou is met die oog op die stryd terwille van sy eiendomme wat die Ned Herv Kerk later moes voer (Botha 1981:65). Die voorgestelde wysigings het egter vir Goddefroy en die Nederduitsch Hervormde Kerk 'n onaangename nasleep gehad, toe ds H S Bosman van die Nuwe Verenigde Kerk, maar vroeër van die Nederduitsch Hervormde Kerk, aan die begin van 1889 in die koerante 'n bittere aanval op die kerk en sy enigste predikant geloods het en onder andere beweer het dat Goddefroy en die Nederduitsch Hervormde Kerk met die oorweging en aanvaarding van die nuwe ondertekeningsformule die hartlike quia (omdat) laat vaar het ten gunste van die betekenislose quatenus (in soverre), en daarmee is die spoor van Dordt verlaat en leervryheid die kerk 
ingesmokkel en word so niks minder nie as die ondergang van die Christendom beoog (Botha 1981:87). Goddefroy het die bewering van Bosman as vals en kwetsend beskou en onomwonde verklaar: "Ook hierin spreekt Ds B geheel bezijden de waarheid, aangezien het voor mij ten alle tijde en ook nu nog een ongerijmdheid is by de onderteekening van de Formulieren eener Kerk te spreken van, of te denken aan een quatenus, waardoor de gehele ondertekening willekeurig word, en gelijk staat met niet ondertekening" (Goddefroy 1890:19).

\section{ONDERTEKENING VAN DIE FORMULE: LETTERLIK OF' 'N BLOTE FORMALITEIT?}

Op 7 Julie 1911 het ds C J L Ruysch van Dugteren, predikant van Pretoria, aan die Kommissie van die Algemene Kerkvergadering 'n brief geskryf waarin hy by die Kommissie navraag gedoen het hoe hy sy ondertekening van die ondertekeningsformule moes vertsaan. Hy het onder andere geskryf:

Ik erken dat op zichzelf deze formule duidelik genoeg is - maar toch schijnt mij, ziende op historisch geworden toestanden, de vraag gettigd of ik mij houden moet aan de letterlijke verklaring van bogenoemde formule, - zoodat iedere - ook de geringste afwijking van de leer, in de drie formulieren van Eenigheid vervat, moet beschouwd worden als ' $t$ schenden van de belofte bij in dienst treding afgelegd - of is afwijking van de leer geoorloofd? ... Zou het u mening mocht zijn, dat ik mij als predikant te houden heb aan de belofte bij in dienst treding afgelegd, - dan voel ik mij gedrongen hier openlijk te verklaaren, dat ik de leer in de drie formulieren van Eenigheid vervat niet volkomen kan gelooven overeenkomstig Gods Woord te zijn.

(NHK Argief:AII/F/c)

Van Dugteren se dilemma was dat, terwyl hy met sy handtekening onder die ondertekeningsformule verklaar het dat hy wel geglo het dat die leer van die kerk, soos in die formuliere van eenheid vervat ooreenkomstig die Woord van God was, hy dit tog nie geglo het nie. Wat hy in sy brief aan die Kommissie gevra het was niks minder nie as dat 
die Kommissie dit aan hom moes toestaan " ... om die kerkleer na eie goeddunke te verwerp en sy ondertekening nie as letterlik te beskou nie" (Engelbrecht 1953:371)

Die Kommissie van die Algemene Kerkvergadering het op 7 en 8 September 1911 onder voorsitterskap van ds Goddefroy besluite geneem wat daarop neergekom het dat:

- afwyking van enige deel van die leer wat in die drie formuliere van eenheid vervat was, strydig was met die belofte wat met die ondertekening van die formule afgelê is;

- in die Nederduitsch Hervormde Kerk geen leervryheid toegelaat kan word nie omdat dit tot ontbinding van die Kerk sou kon lei;

- deur hom nie te hou aan die formule wat hy onderteken het nie, het Van Dugteren homself aan die predikantsamp van die Ned Herv Kerk onttrek (Botha 1981:202).

Die Algemene Kerkvergadering het op 30 April 1912 die beslissing van die Kommissie van die Algemene Kerkvergadering bekragtig en daarmee was die Van Dugterensaak formeel afgehandel. Intussen het in die gemeente Pretoria onder leiding van 'n bekwame juris, dr H D J Bodenstein, 'n sogenaamde waaksaamheidskomitee tot stand gekom met die bedoeling om lidmate in te lig dat die bestaande ondertekeningsformule "... niet door alle predikanten gewetensvol kunnen worden onderteekend, ofschoon zij anders wel hun geloof baseren op Gods Woord" (Bodenstein 1911:2). Bodenstein self het 'n brosjure die lig laat sien onder die titel: Schorsing van ds Ruysch van Dugteren: Word de Hervormde Kerk Roomsch? In die geskrif waarin allerlei beskuldigings teen die Ned Herv Kerk ingebring is, is Goddefroy ook betrek met verwysing na sy bekende standpunt dat die kerkleer (= mensewoord) nooit gelykgestel mag word met die Woord van God nie. Dit het Goddefroy genoop om te antwoord in 'n brosjure onder die titel: Neen Niet Roomsch! In die derde hoofstuk met die titel "Gebondenheid van leerars en leden aan eigen belijdenis en belofte" stel Godefroy die standpunt van die Ned Herv Kerk so:

Tegenover "Kerkgezag en gewetensdwang" van Rome stellen de Kerken der Hervorming 'gebondenheid aan eigen Belijdenis en Belofte.

Is dit $\mathbf{z 0 0}$ onredelijk? 
Waar Rome gezag uitoefent over de gewetens der menschen; haar Belijdenis van boven af oplegt en decreteert; en de Belijdenis desnoods te vuur en te zwaard op de keel drukt harer leden! Daar vraagt de Hervormde Kerk net so onders (niets meer maar ook niets minder) dan eerlijke uitvoering van eigen belofte en kontrakt, gemaakt ten aansien van het geloof der gemeenschap, neergelegd in de Formulieren; opgemaakt doot de wettige daartoe verkozen vertegenwoordigers der Gemeente.

(Goddefroy 1912:21)

Terwyl die grondslag van die Ned Herv Kerk en sy belydenis enkel en alleen die geopenbaarde Woord van God is, is dit vanselfsprekend dat ook met die belydenis wat uit die Woord geneem is, in die grootste erns omgegaan moet word. Geen willekeur rondom die belydenis is toelaatbaar met die houding: “... ik zal deze in de Kerk; van den Kansel, en overal waar het mij behaagt; behandelen, verklaren en uitleggen, naar eigen meening, inzicht en goeddunken!' ' $I k$ ' de regel! 'Ik' de onfeilbare! 'Ik' de souvereine Macht! ... Dat nooit" (Goddefroy 1912:22).

'n Quatenus-standpunt, wat op 'n voorwaardelike ondertekening van die formule neergekom het, was vir Goddefroy eenvoudig onsinnig en hy het dit beskryf as niks anders nie as die Jesuïtiese "reservatio mentalis".

\section{TAALKUNDIGE VERSORGING BRING UITBREIDING EN VERANDERING}

Tydens die Algemene Kerkvergadering van 1979 is 'n omvattende taalkundige versorging van die Kerkwet en Bepalings, met insluiting van die ondertekeningsformule, oorweeg en aanvaar. Prof S J Botha het op 21 April 1982 'n memorandum aan die Kommissie van die Algemene Kerkvergadering voorgelê, waarin hy betoog het dat daar veranderings aan die ondertekeningsformule aangebring is wat nie net taalkundig van aard was nie en hy het die vraag gestel of die Algemene Kerkvergadering wel bewus was van die uitbreiding en verandering wat aangebring is. Dit het vir hom veral gegaan oor die afsluitende sin van die ondertekeningsformule, wat toe gelui het: "Deur hierdie formule te onderteken, verklaar ek/ons dat ek/ons vas oortuig is en glo dat die leer wat in 
die formuliere van eenheid uitgedruk is, in volkome ooreenstemming met die Woord van God is" (NHKA 1979:288). Hy het die volgende argumente aangevoer om sy probleem aan te toon:

1 Die woorde "vas oortuigd is" kom nie in die oorspronklike sin voor nie nóg in die Nederlands nóg in die Afrikaans. Dit is dus ' $n$ uitbreiding en die vraag kan gevra word of die glo nie die gedagte van "vas oortuigd" wees insluit nie. Waarom dan die uitbreiding? Dit verander egter nie die betekenis nie.

2 Van ' $n$ ander aard is die tweede uitbreiding deur die invoeging van die woord "volkome" voor "ooreenstemming". Dit bring inderdaad 'n verandering van betekenis mee omdat daarmee gesê sou word dat die kerklike belydenisskrifte "volmaak" is. Op die wyse word Gods Woord en mensewoord op een lyn met mekaar gestel. In die Nederduitsch Hervormde Kerk is selfs die geringste sweem van so 'n gelykstelling nog altyd afgewys.

3 Dit wil voorkom of die veranderinge moontlik vanuit die Dordtse Ondertekeningsformule van 1619 hier ingeskryf kon gewees het maar dan tog op ' $n$ foutiewe vertaling berus.

(Botha 1982b:2)

Hy verwys dan na die woorde ghevoelen ende geloven en in alles met Gods woort over een comen. In hierdie verband stel hy:

Die woorde in alles sou in Afrikaans ook met in alles vertaal kon word met die bedoeling dat die belydenisskrifte in alle dele, dit wil sê nie net in hoofsaak nie maar ook in elke onderafdeling, met Gods Woord ooreenkom, maar nie met volkome nie omdat dit die betekenis kan hê dat die leer soos in die belydenisskrifte deur die kerk geartikuleer volmaak ooreenstem met Gods Woord en dus aan Gods Woord gelyk is. Dit sou die belydenisskrifte verabsoluteer en inhou dat hulle prinsipieel onveranderbaar is.

Oor die woord volkome is daar in die geskiedenis van die Nederduitsch Hervormde Kerk reeds uitsprake gemaak. In die Ruysch van Dugteren-saak 1911 en 1912 het die woord volkome in die verband telkens opgeduik. Van 
Dugteren self het verklaar “... dat ik de leer in de drie formulieren van eenigheid vervat niet volkomen kan gelooven overeenkomstig Gods Woord te zijn".

Dr H D J Bodenstein, wat die pen vir Van Dugteren opgeneem het, het ook daarna verwys:

... dat hij (Van Dugteren) de leer der uitverkiesing, zoals geleerd in de Leerregelen van Dordt en in de belijdenis niet volkomen overeenkomstig Gods Woord beschouwde. Let wel, dat zijn standpunt niet is dat de leer van de uitverkiesing niet overeenkomstig Gods Woord is, maar niet volkomen. Met de grondbeginselen van de leer is hij het eens.

Wat beide bedoel het was dat Van Dugteren aanvaar het dat sekere dele van die belydenisskrifte wel en sekere dele nie ooreenkomstig die Woord van God was nie. Deur egter die woord volkome te gebruik, word die suggestie gelaat dat die kerk aanspraak daarop gemaak het dat die leer van die uitverkiesing, soos in die belydenisskrifte geartikuleer, volmaak ooreenkomstig Gods Woord was. Hierteen het ds Goddefroy ernstig beswaar gehad:

Ziet, dat gedurig schermen met het woord volkomen maakt de zaak voor hem (Bodenstein) en zijn klient (Van Dugteren) nog zwakker. Er zijn geen volkomen Belijdenisschriften, en aan onze zijde is er nimmer volkomen werk. Terecht wordt in de ondertekeningsformule dit woord dan ook niet gebruikt, maar wel het duidelijke en eenvoudige en ondubbelzinnige "de ondertekenaar dezer formule verklaart door zijn handteekening, dat hij de leer, die in bovengenoemde formulieren vervat is, gelooft overeenkomstig Gods Woord te zijn. Waarom telkens geschermd met het woord volkomen .... Die hooggererde vaderen word door ... dat gedurig gescherm met volkomen toch eigelijk in een verkeerde daglicht gesteld."

Goddefroy se argument het berus op sy siening dat “ ... iedere Belijdenis voor ons is: een onvolkomen uitdrukking van het geloof der Gemeente; welke zeer zeker een gedurige Bijbeldoop van noode heeft; ..."

(Botha 1982:4) 
Botha se konklusie was:

1 Dit is duidelik dat die betrokke sin in die ondertekeningsformule in 1979 nie net taalkundig versorg is nie, maar inderdaad uitgebrei en verander is deur die invoeging van die woorde vas oortuigd is en volkome.

2 Daar sal ' $n$ beslissing deur die Kerk geneem moet word of by die uitbreiding en verandering volstaan gaan word.

(Botha 1982 (b):4)

Die Kommissie van die Algemene Kerkvergadering het die reaksie op hierdie skrywe, soos deur prof B J Engelbrecht opgestel, volledig onderskryf (Smith 1982:1).

Vanwer die feit dat hier 'n amptelike uitleg van 'n bepaalde gedeelte van die ondertekeningsformule gegee is, word dit volledig hier weergegee:

1 Graag wil ek my waardering uitspreek teenoor prof Botha beide vir sy opmerksaamheid en vir die gebruik van die relevante historiese stof uit die verlede van ons kerk in sy argumentvoering.

2 Tereg stel prof Botha dat die toevoeging van vas oortuigd (in die sinsnede "Deur hierdie formule te onderteken, verklaar ek dat ek vas oortuigd is en glo ..."), wesenlik niks aan die betekenis verander nie (punt 1 bl 509). Ek beskou die toevoeging eerder as 'n wins, omdat dit die woord glo in hierdie sinsnede tereg onderstreep en versterk. Ek glo kan in Afrikaans ook beteken ek neem dit aan, maar is nie heeltemal seker nie, soos in die sinsnedes: Het Piet al gekom? Ek glo so. Die sinsnede vas oortuigd sny hierdie betekenis van $e k$ glo by die wortel af.

3 Ook oor die feit dat dit ' $n$ integrale deel van die reformatoriese teologie is dat die belydenisskrifte nie met die Heilige Skrif gelykgestel mag word nie, maar prinsipieel altyd oop is vir korreksie vanuit die Heilige Skrif, stem ek met prof Botha heelhartig saam. Om hierdie stand van sake uit te druk, is in die reformatoriese tradisie gestel dat albei, Skrif en belydenis, normatief vir die geloof en lewe van die gelowige is, maar dat die belydenis norma normata (gemete norm) is en die Heilige Skrif norma normans, dit wil sê die oorspronklike norm waaraan die norma normata gemeet word. 
4 Praat ons van die kerklike belydenis as sodanig, dan is dit volkome reg om te sê dat dit prinsipieel nie volkome is nie en nie met die Skrif gelykgestel mag word nie.

5 Maar praat ons van die akte van die kerklike belydenis, van iemand wat hier-en-nou sy geloof bely, dan moet ons sê dat so 'n belydenis vir die belyer niks anders kan en mag wees as dit wat oor hierdie bepaalde saak in die Skrif staan nie. Die belydenis moet in die belydenisakte volkome ooreenkom met wat die Skrif sê, want wat help dit as ek as belyer iets bely, maar in my gemoed twyfel of dit werklik volkome met die Skrif ooreenkom. So 'n belydenis is eintlik geen egte geloofsbelydenis nie. Kortom: Op die comblik dat iemand in actu bely, mag die belydenis niks anders wees as die Skrif wat hier en nou die volle waarheid oor die bepaalde saak aan my meedeel nie. 'n Belyer mag (as hy 'n egte belyer wil wees) nooit ten opsigte van sy belydenis hier-en-nou 'n reservatio mentalis hê, 'n geestelike voorbehou dat sy belydenis van nou, tog later uit die Skrif verkeerd kan blyk te wees nie. In die aktuele daad van belydenis, moet die belydenisinhoud en die Skrifinhoud vir die belyer volkome saamval.

6 Daarom is dit myns insiens volkome korrek as die ondertekenaar van die Proponentsformule in sy aktuele daad van belydenis verklaar dat hy "... vas cortuig is en glo dat die leer wat in die formuliere van eenheid uitgedruk is, in volkome ooreenstemming met die Woord van Gods is."

7 Laat ek ten slotte die saak vanuit 'n ander hoek benader, naamlik die bekende strydpunt of die formuliere onderskryf moet word quia (= omdat) hulle ooreenkom met die Woord van god, of quatenus (= in soverre as wat) hulle coreenstem met die Woord van God?

(a) Die quatenus-standpunt is in dié sin reformatories omdat dit die weg van die korreksie van die belydenisskrifte vanuit die Skrif prinsipieel oophou. Dit kan dus wel die Kerk se standpunt in sy besinning oor die belydenisskrifte wees, maar dit kan nooit as standpunt vir 'n ondertekenaar van die proponentsformule geld nie, want dan sal dit impliseer dat die Kerk op ' $n$ bepaalde tydstip in die belydenisskrifte 'n sekere aantal hoofpunte sal hê wat met die Skrif ooreenkom, maar 'n sekere hoofpunt of aantal hoofpunte wat nie met die Skrif coreenkom nie; die ondertekenaar sal in die genoemde situasie dan weet watter punte dit is wat nie met die Skrif klop nie, en sal dan persoonlik daaroor die regte leerstellings hê wat wel met die Skrif coreenkom. Hy het 
dan geloofswaarhede wat die Kerk nie het nie en wat van die Kerk se verstaan van die Skrif verskil.

(b) Die enigste standpunt wat vir 'n ondertekenaar in sy akte van belydenis kan geld, is die quia-standpunt. Hy onderteken die formule hier-en-nou vas oortuig is dat die belydenisse in alles volkome ooreenkom met die Skrif. Hy kan wel later, indien hy ontdek dat die Skrif op 'n sekere punt of punte anders leer as die belydenis, by wyse van 'n gravamen die Kerk versoek om vanuit die Skrif ' $n$ moontlike korreksie aan te bring aan die belydenis. Maar met hierdie moontlikheid reken die ondertekenaar by sy akte van ondertekening gladnie, omdat hy vanuit die Skrif van geen verskilpunt weet tussen Skrif en belydenis nie. Weet hy wel van so ' $n$ punt, dan mag hy nie met ' $n$ goeie gewete die formule onderteken nie.

8 Ek sal dus graag die ondertekeningsformule hou soos dit tans is en eerder nog die in alles van die Dordtse ondertekeningsformule van 1619, voor in volkome ooreenstemming wil invoeg.

(Engelbrecht 1982:1-3)

\section{DIE KERKORDE VAN 1997}

Op die Algemene Kerkvergadering van 1989 is besluit om 'n grondige hersiening van die Kerkwet en Bepalings te onderneem (NHKA 1989:44) en daarvoor 'n kommissie van ondersoek en studie aan te wys met die oog op herformulering, en aanpassing indien nodig (NHKA 1989:274). Die Kommissie het by die Algemene Kerkvergadering van 1992 aanbeveel dat 'n totale nuwe Kerkwet daargestel moes word (NHKA 1992:259). Die Komitee vir die herskrywing van die Kerkwet het, nadat wyd in die Kerk gekonsulteer is, teen die einde van Junie 1997 'n finale konsep aan die Buitengewone Algemene Kerkvergadering voorgelê, wat met geringe wysigings deur die Vergadering goedgekeur is en wat op 1 Januarie 1998 in werking getree het (NHKA 1997).

Ook die voorgestelde nuwe ondertekeningsformule is met geringe wysiging goedgekeur:

Ordidansie 1.1.2

Kandidate vir die amp van dienaar van die Woord onderteken voor beroepbaarstelling die volgende formule: 
Ek verklaar hiermee dat ek die leer wat uitgedruk is in die formuliere van eenheid, naamlik die Nederlandse Geloofsbelydenis, die Heidelbergse Kategismus en die Dordtse Leerreëls van harte onderskryf en dat ek daarvan vas oortuig is en glo dat dit volkome in ooreenstemming is met die Woord van God. Ek beloof om in hierdie leer te volhard en my in my verkondiging hierdeur te laat tét. Ek beloof om my te hou aan die Kerkorde van die Nederduitsch Hervormde Kerk van Afrika. By oortreding daarvan sal ek my onder. werp aan die oordeel van die bevoegde kerklike vergaderings.

Die vernaamste verandering wat die Algemene Kerkvergadering aan die konsep aangebring het, was om die woord volkome in te voeg (NHKA 1997). Op die Algemene Kerkvergadering van 1998 is daar egter weer besluit om die woord volkome weg te laat (NHKA 1998:2-3). Ook ten opsigte van die ondertekeningsformule het die Komitee vir die herskrywing van die Kerkwet so wyd moontlik in die Kerk gekonsulteer en met sowel die gegewens uit die verlede as die kommentaar en voorstelle wat ontvang is tot sy beskikking indringend besin (kyk bv NHKA 1995:bylae I; NHKA 1996a; NHKA 1996b). Vergelykenderwys is daar geen wesenlike verskil tussen die nuwe formule en die een wat sedert 1866 tot 1997 van krag was nie, selfs nie die invoeging of die weglating van die woord volkome kan daaraan enige verskil maak nie. Soos aangetoon het die woord volkome tot in 1979 ook nie in die vorige ondertekeningsformule voorgekom nie. Die formule kan ook nie so geïnterpreteer word dat 'n quatenus-ondertekening moontlik is nie. Bowendien is die binding aan die Kerkorde, veral ook ten opsigte van die belydenis, van baie groot belang. Twee aanhalings uit die Kerkorde sal dit genoegsaam illustreer:

Ordereël 1

1.1 Die leer van die kerk soos verwoord in die belydenisskrifte geld vir ons as

1.1.1 samevatting van die wesenlike van die geloof

1.1.2 norm vir die verkondiging

1.1.3 basis van die kerklike onderrig

1.1.4 maatstaf vir teologiese onderrig en uitsprake

1.1.5 rigsnoer vir kerklik-teologiese uitsprake. 


\section{Ordinansie 1}

1.1 Kerk se binding aan die belydenis

1.1.1 Binding aan die belydenis, soos vervat in die belydenisse en belydenisskrifte, geld vir alle lidmate.

1.1.3 Opsighoudende vergaderings handel volgens die kerklike dissipline met ampsdraers en lidmate wat nie aan die belydenis getrou bly nie.

(NHKA 1997:1 en 4)

Behalwe hierdie reèlings ten opsigte van die binding van ampsdraers en lidmate van die Kerk aan die belydenis van die kerk, is in die Kerkorde ook die nodige reëlings getref om die belydenisskrifte te kan verander, ander of nuwe belydenisskrifte te kan aanvaar en besware teen kerklike leerbeslissings te kan voorlê (kyk NHKA 1998:4 en 5).

\section{TEN SLOTTE}

Die ou beproefde tradisie van die Nederduitsch Hervormde Kerk bly gehandhaaf. Terwyl die Skrif steeds as die absolute norm geld (norma normans), word nie toegelaat dat argeloos met die kerk se belydenis omgegaan word en die Kerk se belydenisskrifte gering geskat word nie.

\section{Literatuurverwysings}

Bodenstein, H D J 1911. Wordt de Hervormde Kerk Roomsch? Potchefstroom: Het Westen Drukkery.

Botha, S J 1963. Die historiese agtergrond van die Kerkwet van 1862 van die Ned Hervormde Kerk in die Z A R, HTS 19, 25-35

- 1981. Ds Marié Joseph Goddefroy 1848-1920 sy lewe en betekenis. Pretoria: HAUM.

- 1982a. Die belydenis in kerkregtelike verband. HTS 38(2\&3), 30-45.

- 1982b. Memorandum in sake proponentsformule aan die Kommissie van die Algemene Kerkvergadering. Pretoria: NHKA.

- 1993. Die heil, gehoorsaamheid, struktuur en kerkreg. Publikasies van die Universiteit van Pretoria (nuwe reeks), no 285. 
Engelbrecht, B J 1982. Memorandum aan die Kommissie van die Algemene Kerkvergadering. Pretoria: NHKA.

Engelbrecht, S P 1953. Geskiedenis van die Nederduitsch Hervormde Kerk van Afrika. Derde uitgawe. Kaapstad-Pretoria: HAUM-De Bussy.

- sa. Dr G D Scholtz se Geskiedenis van die Nederduitse Hervormde of Gereformeerde Kerk. Pretoria: HAUM.

- sa. Nogmaals dr G D Scholtz se Gekiedenis van die Nederduitse Hervormde of Gereformeerde Kerk. Pretoria: HAUM.

Goddefroy, M J 1890. De Kerkkwestie niet een leer-maar een levenskwestie. Tweede druk. 's Gravenhage: De Swart en Zoon.

- 1912. Neen niet Roomsch! Pretoria: De Atlas Drukkery.

- 1991. Die Kerkkwessie nie 'n leer, maar 'n lewenskwessie, vertaal deur S J Botha. Pretoria: Kital.

Nederduitsch Hervormde Kerk van Afrika 1951. Kerkwet en Bepalings van die Nederduitsch Hervormde Kerk. Pretoria: NHKA.

- 1964. Notule van die vier-en-vyftigste Algemene Kerkvergadering van die Nederduitsch Hervormde Kerk. Pretoria: NHKA.

- 1979. Agenda met Bylaes van die Nege en vyftigste Algemene Kerkvergadering van die Nederduitsch Hervormde Kerk. Pretoria: NHKA.

- 1989. Notule van die twee-en-sestigste Algemene Kerkvergadering van die Nederduitsch Hervormde Kerk van Afrika. Pretoria: NHKA.

- 1992. Notule van die drie-en-sestigste Algemene Kerkvergadering van die Nederduitsch Hervormde Kerk van Afrika. Pretoria: NHKA.

- 1995. Agenda vir die vergadering van die Komitee vir die herskrywing van die Kerkwet van 19 Januarie 1995, Bylae I.

- 1996(a). Kerkorde tweede konsep vir voorlegging aan kerkrade en predikante. Pretoria: NHKA.

- 1996(b). Notule van die vergadering van die Komitee vir die herskrywing van die Kerkwet van 31 Julie 1996. Pretoria: NHKA.

- 1997. Kerkorde van die Nederduitsch Hervormde Kerk van Afrika. Pretoria: NHKA. 
Nederduitsch Hervormde Kerk van Afrika 1998. Besluitebundel van die 65ste Algemene Kerkvergadering van die Nederduitsch Hervormde Kerk van Afrika. Pretoria: NHKA.

Pont, A D 1955. Nicolaas Jacobus van Warmelo 1835-1892. Utrecht: Kemink en Zoon.

- 1963. Oor die Kerkwet van 1862. HTS 19(1\&2), 36-46.

Praamsma, L sa. De belijdenis in de krisis. Wageningen:N V Gebr Zomer \& Keunings Uitgeversmaatschappij Reitsma, en Lindeboom.

Smith, P M 1982. Brief in sake memorandum proponentsformule. Pretoria: NHKA.

Vorster, J D 1956. Die kerkregtelike ontwikkeling van die Kaapse Kerk onder die Kompanjie 1652-1792. Potchefstroom: Pro Rege.

Kleynhans, E P J 1974. Die kerkregtelike ontwikkeling van die Nederduitse Gereformeerde Kerk in Suid-Afrika 1795-1962. DD-proefskrif, Universiteit van Stellenbosch. 